\title{
THEORETICAL SUBSTANTIATION OF PARAMETERS OF ROTARY SUBSOIL LOOSENER
}

\author{
Ayrat Valiev ${ }^{1}$, Ilshat Mukhametshin ${ }^{1}$, Farzutdin Muhamadyarov ${ }^{2}$, Fanis Yarullin ${ }^{1}$, Gennady Pikmullin ${ }^{1}$ \\ ${ }^{1}$ Kazan State Agrarian University, Russia; ${ }^{2}$ Vyatka State Agricultural Academy, Russia \\ ayratvaliev@mail.ru, @vgsha.info
}

\begin{abstract}
In recent years, many researchers have paid more attention to the substantiation and determination of the range of optimal (rational) parameters, ensuring a reduction in energy, labor and time, and the effect of mechanical treatment on the soil structure. The article presents the rationale and determination of the design parameters of the rotary subsoil loosener of the combined plough for flat ploughing. Rotational working element is made in the form of a screw cone mounted on a bearing, with the possibility of frictional rotational movement around its own axis from the reaction of the soil, and which is a multiple-thread screw. Oscillatory-rotational movement, which occurs in the process of introducing the ripper-subsoiler into the soil, is due to the uneven resistance of the soil. An analytical study was conducted from the point of view of the impact of soil-cultivating workers on the soil, depending on their design parameters. Analytical dependences of the subsoil loosener were obtained, which allowed substantiating the choice of its design parameters, in particular, the central angle $\beta$ at the top of the cone, the width of the grip, the distance $L$ between the plough bottoms and the resistant subsoil loosener, and the length of the soil splitting. Central angle at the cone apex $\beta$ depends on the depth at which loosening occurs, the extension length of the cone apex from the tine and the rear cutting angle of the subsoil loosener.Minimal acceptable distance from the subsoil loosener's tine to the combined tillage machine's bottom depends on the depth of loosening, rear cutting angle, cone apex angle $\beta$ and the physical-mechanical properties of the soil. These dependences determine the possibility of a stable rotational workflow, which is reduced to a constructive implementation after the calculation of its basic parameters. The obtained analytical dependences and some prerequisites can be used both in the study and in the design of such rotary working bodies.
\end{abstract}

Keywords: tillage, flat ploughing, subsoil loosener, drag kernel, design parameters.

\section{Introduction}

Improving tillage efficiency implies reductions in energy consumption, labour and time required with simultaneous rise in tillage quality. In order to ensure tillage efficiency working elements of tillage machines have to be designed on a rational basis. Substantiation of parameters of the working elements draws attention of many researchers [1-4]. It is known that technological and energy indicators of the efficiency of tillage machines, in addition to the parameters of the working elements, largely depend on the physical and mechanical properties of the treated soil [5-8]. Therefore, when designing new working elements of tillage machines, it is essential to obtain analytical dependencies to substantiate the rational values of the elements' design parameters, which will ensure high quality tillage with minimal energy costs [9-12]. We have developed a combined plough for flat ploughing with conical rotary subsoil loosener [13]. The objective of this study is to obtain analytical dependencies for substantiating design parameters of the subsoil loosener, namely the central angle at the cone apex, the distance between the plough body and the subsoil loosener's tine, the cone extension length against the tine, the rear cutting angle and the length of the cone's working section.

\section{Materials and methods}

The combined plough for flat ploughing (Fig. 1) consists of a frame, a disk knife, pushers, rightturning and left-turning plough bottoms with cylindrical mouldboards, and a subsoil loosener mounted behind the central plough bottom.

The study considers two types of subsoil looseners. The first type is a sweep share and the second - the new conical rotary subsoil loosener.

Overall view of the screw conical rotary subsoil loosener is shown in Fig.2. Its working element is a multiple-thread screw designed in the form of a cone with the screw surface mounted on a bearing with the ability to rotate around its axis.

The main research results are obtained on the basis of theoretical study using methods of mechanics, analytical geometry and laws of agricultural mechanics. 


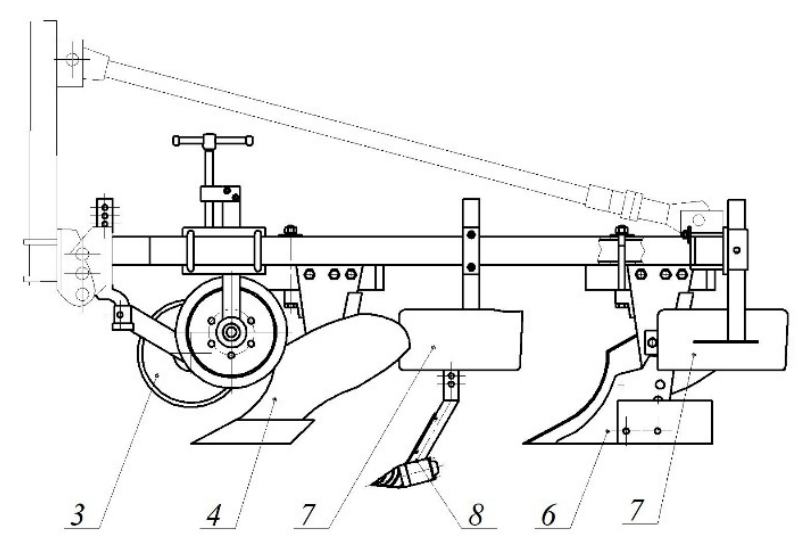

a)

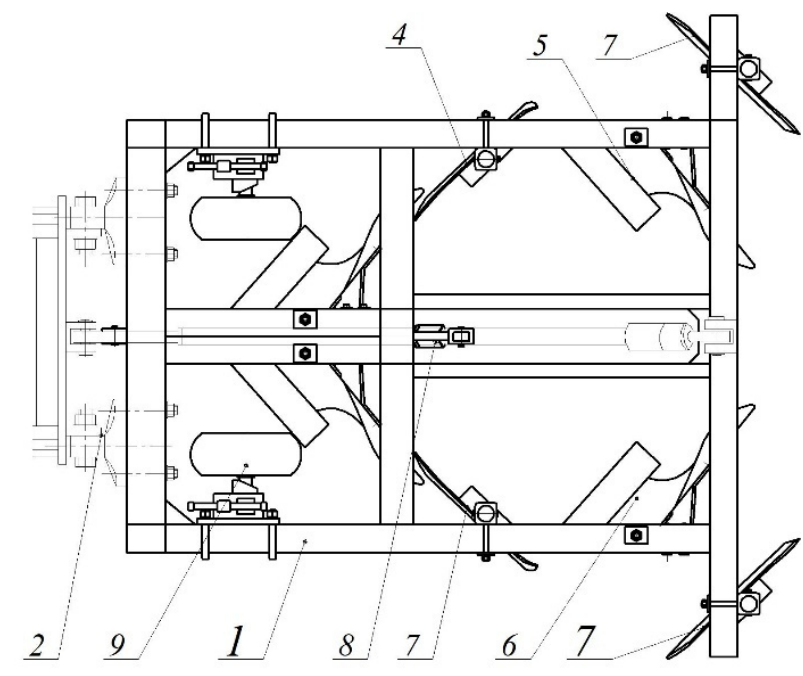

b)

Fig. 1. Combined plough for flat ploughing with conical rotary subsoil loosener: $a$ - side view; $b$ - view from above; 1 - frame; 2 - disk knife; 3 - dual bottom; 4,5 - first and second row pushers;

6, 7 - right-turning and left-turning bottoms; 8 - subsoil loosener; 9 - adjustment wheels

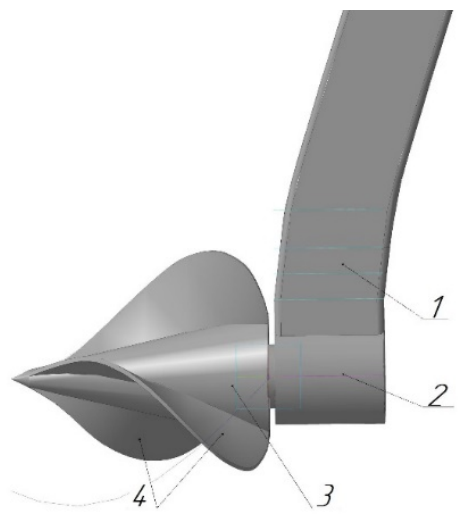

Fig. 2. Overall view of screw conical rotary subsoil loosener: 1 - tine; 2 - bearing unit; 3 - cone; 4 - screw wings

\section{Results and discussion}

Results of numerous researches indicate that the soil deformation zone is not limited to the area of interaction between the soil and the working body, but stretches forward and sideways to significant distances. Soil acts as viscoelastic plastic medium.

Layer of soil sliding on the working surface of a wedge-shaped sweep share is being acted on by the normal force $N$ and by the friction force $F$, causing the resultant force $R$, inclined at a friction angle $\varphi$ to the normal. According the tangential stress theory directions $H_{1}$ and $H_{2}$, in which the soil layer is destroyed as a result of shearing, are symmetrical to the resultant force $R$ with a shearing angle $\theta$ between them. For the majority of soils this angle lies between $40^{\circ}$ and $50^{\circ}$ [14]. This fact suggests that the directions of soil shearing do not significantly deflected from the resultant force $R$.

In the cross-vertical plain $[14 ; 15]$ the soil deformation zone is also constrained by plains with the angle $\theta$ between them. Then (Fig.3,a) the soil deformation zone caused by loosening share will amount to:

- along the movement direction

$$
L=l_{0}+l_{1}=l_{0}+a \cdot \operatorname{tg}(\alpha+\varphi),
$$

- across the movement direction 


$$
b_{1}=b_{0}+2 a \cdot \operatorname{tg} \cdot \frac{\theta}{2},
$$

where $a$ is the depth of loosening.
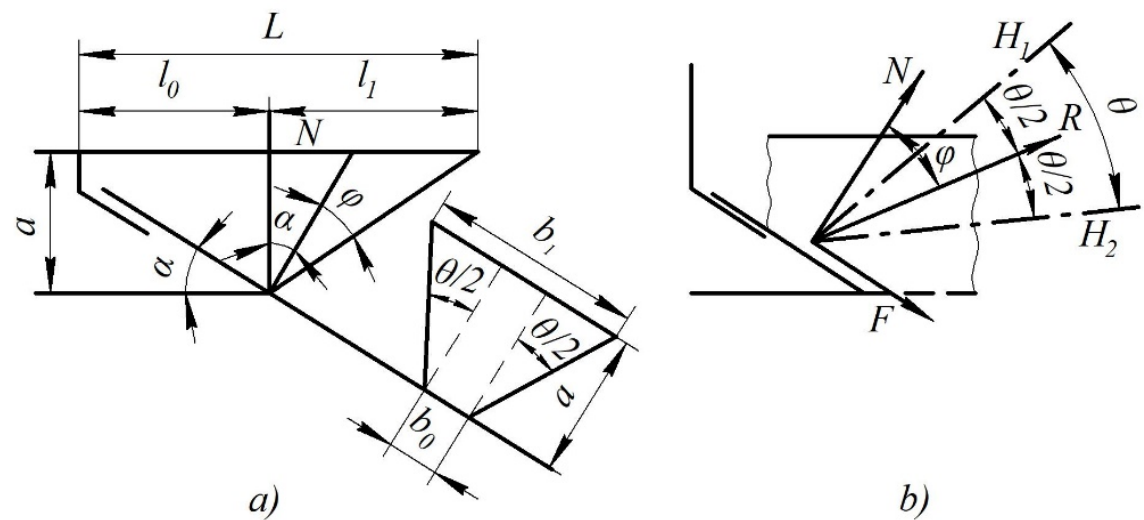

b)

Fig. 3. Scheme of soil layer deformation by loosener's sweep share: $a$ - deformation zones in longitudinal and transversal directions; $b$ - forces and directions of shearing cracks

For schematization of the study process it is possible to assume that shearing occurs along the Rforce (Fig. 3), as this direction is a symmetry axis of the sliding lines. On the bases of this, V. S. Zhegalov determined the width of the soil deformation stripe for flat wedge using the following formula:

$$
B=d+\frac{2 \cdot H \cdot t q \frac{\theta}{2}}{\cos \left(\varphi+\alpha_{0}\right)},
$$

where $B-$ width of the deformation stripe, $\mathrm{m}$;

$d$ - working width of the wedge, m;

$H$ - working depth of the width, m;

$\alpha_{0}$ - angle of the sweep share's breast, degree.

During cutting with sliding tension and shear stress occurs. Since the tensile and shear strength of the majority of materials is greater than the bearing strength, this leads to weakening of the cutting resistance forces.

Taking this into account, let us study the movement of the subsoil loosener in the subsoil. The angle of the share to the furrow bottom $\beta$ (Fig. 4) is in fact the cutting angle and corresponds to the $\varepsilon$ angle of the plough share. The greater this angle is, the better the soil crumbles, however, the subsoilers' drag force increases significantly. Typically this angle is within the range $30^{\circ} \ldots 40^{\circ}$. During blade sharpening at $14^{\circ} \ldots 16^{\circ}$, angle the rear angle of the blade will be $15^{\circ}$ or more, which is acceptable.

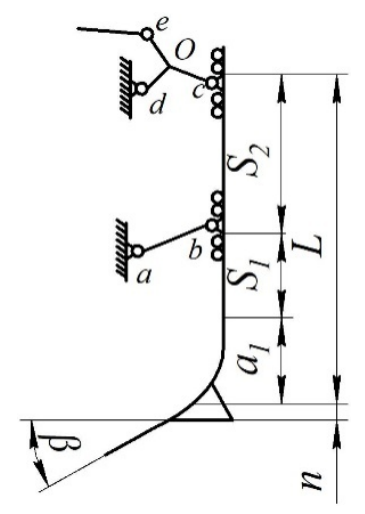

Fig. 4. Subsoiler scheme 
In order to avoid the share clogging with plant roots, the apex angle of the share $2 \gamma$ should be taken smaller than doubled value of $90-\varphi$, i.e. $\gamma<90-\varphi$.

Resolving normal reaction $R$ of the share blade along the direction of its movement $R^{\prime}$ and along the blade $R^{\prime \prime}$ (Fig. 5) we will get:

$$
R^{\prime \prime}=R \cdot \operatorname{ctg} \gamma
$$

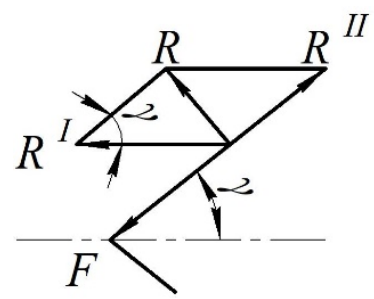

Fig. 5. To design of subsoil loosener

The force $R^{\prime \prime}$ strives to move soil particles and roots along the share blade. The friction force $F=\operatorname{Rtg} \varphi$ resists to this movement. Under the condition $R=\operatorname{Rctg} \gamma \geq \operatorname{Rtg} \varphi$, i.e. when $\operatorname{tg}(90-\gamma) \geq \operatorname{tg} \varphi$, or $\gamma \leq 90-\varphi$, the roots will come off the blades without clogging the share.

Let us determine the length of the subsoiler tine. It can be done using the kinematical scheme of the subsoiler lifting mechanism (Fig. 5):

$$
L=a+s_{1}+s_{2}-n
$$

where $a$-depth at which loosening occurs, $\mathrm{m}$;

$s_{1}$ - minimal height of the swivel point b above the furrow bottom when the plough is in the working position, $\mathrm{m}$;

$s_{2}$ - maximal length of the link $c b$ of the four-bar linkage $a b c d, \mathrm{~m}$;

$n$ - height of the lower tine's end above the share supporting plane, $\mathrm{m}$.

One of the significant shortcomings of passive working elements is the formation of drag kernel before them, which leads to increase in the drag force and degradation of tillage. Therefore, let us study the second type of subsoil looseners, namely, the conical rotary one developed by us. Its schematic drawing is shown in Fig. 6.

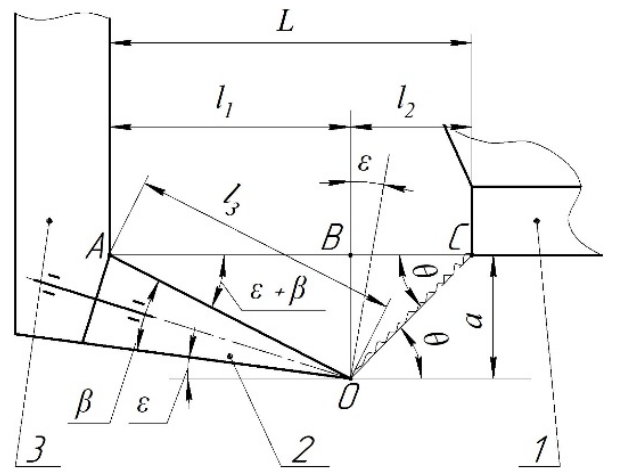

Fig. 6. Schematic drawing of subsoil loosener and its paramters: 1 - plough bottom; 2 - subsoil loosener; 3 - tine; $a$ - loosening depth relative to the plough bottom; $l_{1}$-cone extension length against the tine; $l_{2}$ - distance from the cone apex to the bottom plough; $l_{3}-$ length of the cone working section; $\varepsilon$ - rear cutting angle; $\beta$ - cone apex angle; $\theta$ - soil shear angle

It is necessary to determine the design parameter of the working element - the value of the central angle $\beta$ at the cone apex.

For this purpose let us examine the triangle $\triangle A O B$ (Fig. 6).

$$
\frac{O B}{A B}=\operatorname{tg}(\varepsilon+\beta) \text { or } \frac{a}{l_{1}}=\operatorname{tg}(\varepsilon+\beta),
$$

hence 


$$
\operatorname{tg}(\varepsilon+\beta)=\frac{a}{l_{1}}, \quad \text { or } \operatorname{tg}(\varepsilon+\beta)=\frac{a}{l_{1}}
$$

Finally we can obtain

$$
\beta=\operatorname{arctg}\left(\frac{a}{l_{1}}\right)-\varepsilon .
$$

As the research results show (Fig. 7), the dependency of the apex angle $\beta$ on the loosening depth is close to linear; the value of the angle $\beta$ increases as the loosening depth increases. From the scheme it can also be concluded that with the increase of the extension length of the cone from the tine $l_{1}$ the range of possible values of the angle $\beta$ decreases. It is expected that the increase of the angle $\beta$, when the angle $\varepsilon$ is constant, will lead to sharp increase in the drag force of the working element. Apart from that it is necessary to consider the irregularity of the rotary movement due to torsional oscillation. It is caused by the variability of the soil resistance given the soil's inhomogeneous nature.

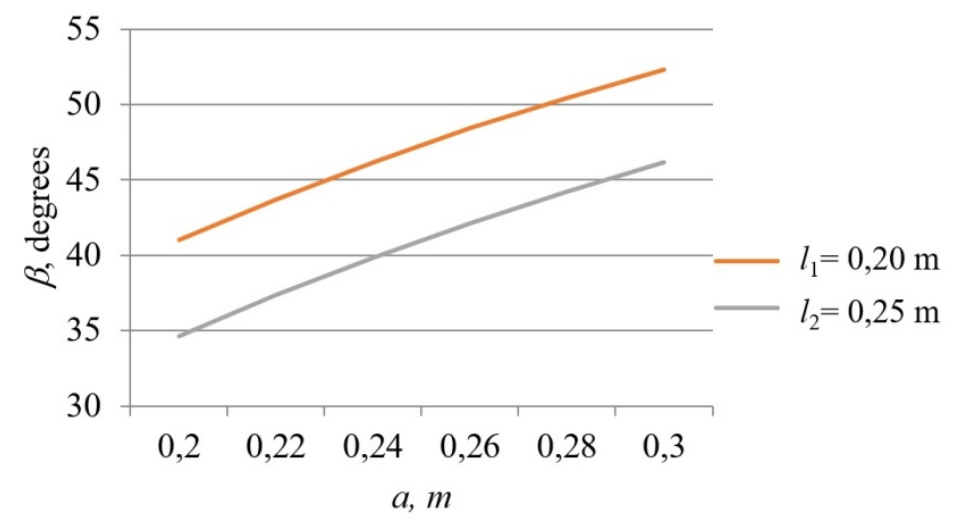

Fig. 7. Angle $\beta$-soil loosening depth $a$ diagram for different extension lengths of cone apex against tine $l_{1}$

In the combined tillage machine one of the important technological parameters is the distance $L$ between the plough bottom and subsoil loosener's tine (Fig. 6).

As seen from Fig. 6:

$$
L=l_{1}+l_{2}
$$

The equation (9) should be met so that working elements are not clogged during the operation.

From equation (7):

$$
l_{1}=\frac{a}{\operatorname{tg}(\varepsilon+\beta)} .
$$

From $\triangle O B C$ :

$$
\frac{B C}{O B}=\operatorname{ctg} \theta
$$

The soil shear angle during working element operation can be determined as

$$
\theta=\frac{\pi}{2}-\frac{\beta+\varepsilon+\varphi+\varphi^{\prime}}{2}
$$

where $\beta+\varepsilon-$ maximal angle of the cone generatrix to the horizontal line,degree.;

$\varphi^{\prime}$ - angle of the inner friction of the soil,degree.

Knowing the soil shear angle $\theta$ and the distance from the cone apex to the plough bottom $l_{2}$, we can obtain: 


$$
\frac{l_{2}}{a}=\operatorname{ctg}\left(\frac{\pi}{2}-\frac{\beta+\varepsilon+\varphi+\varphi^{\prime}}{2}\right) \text {, }
$$

then

$$
l_{2}=a \cdot \operatorname{ctg}\left(\frac{\pi}{2}-\frac{\beta+\varepsilon+\varphi+\varphi^{\prime}}{2}\right) .
$$

Substituting the defined values in equation (9), finally we will obtain:

$$
L=\frac{a}{\operatorname{tg}(\varepsilon+\beta)}+a \cdot \operatorname{ctg}\left(\frac{\pi}{2}-\frac{\beta+\varepsilon+\varphi+\varphi^{\prime}}{2}\right) .
$$

Diagram (Fig. 8) illustrates the dependency of the distance length $L$ between the plough bottom and tine of the working element on the friction angle $\varphi$, when parameters $a, \varepsilon, \beta$ are constant. For the diagram the following values were selected: $\varepsilon=4^{\circ} ; \beta=25^{\circ} ; a_{1}=0,20 \mathrm{~m} ; a_{2}=0.21 \mathrm{~m} ; a_{3}=0.18 \mathrm{~m}$.

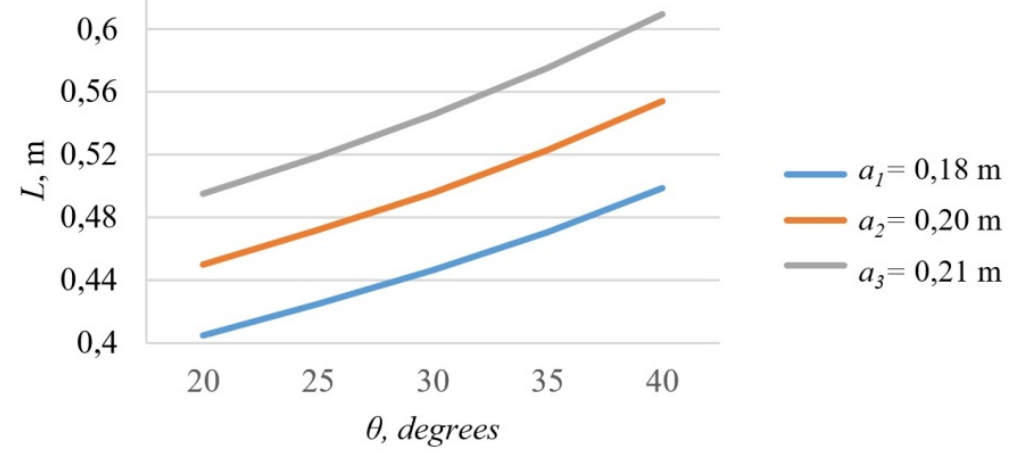

Fig. 8. Distance length $L$ - friction angle $\varphi$ diagram

As it can be seen in the diagram, the distance $L$ between the plough bottom and subsoil loosener's tine is influenced by the angle $\varphi$ as well as by the soil loosening depth $a$. As the angle of friction increases, the minimal distance $L$ increases according to concave parabolic curve.

Knowing the parameter $l_{1}$, it is possible to determine the length of the working section of the cone $l_{3}$ from its apex to the tine.

From $\triangle A O B$ (Fig. 6):

$$
l_{3}=A O=\frac{A B}{\cos (\varepsilon+\beta)}=\frac{l_{1}}{\cos (\varepsilon+\beta)} .
$$

Thus, the length of the working section of the cone depends on the parameters of the cultivated layer technological adjustments.

\section{Conclusions}

1. Construction design of the rotary subsoil loosener, which constitutes a multiple-thread screw designed in the form of a cone with the screw surface mounted on a bearing with the ability to rotate around its axis, has been developed.

2. As a result of the theoretical study analytical dependencies are obtained, which allow substantiation of the design parameters of the rotary subsoil loosener for the efficient tillage process.

3. The central angle at the cone apex $\beta$, depends on the depth a at which loosening occurs, the extension length 11 of the cone apex from the tine and the rear cutting angle $\varepsilon$, which is selected from the range $3^{\circ} \ldots 5^{\circ}$. It is necessary to note that the cone apex angle $\beta$ can be varied only within limited range. The minimal acceptable distance from the subsoil loosener's tine to the combined tillage machine's bottom depends on the depth of loosening $a$, rear cutting angle $\varepsilon$, cone apex angle $\beta$ and the physical-mechanical properties of the soil. The length of the working section of the cone is determined by the parameters of the soil layer and technological adjustments. 


\section{References}

[1] Валиев А.Р., Мухамадьяров Ф.Ф., Зиганшин Б.Г. Обоснование конструктивнотехнологических параметров нового дискового культиватора (Substantiation of the construction and design parameters of the new disk cultivator). Russian agricultural science journal: Российская сельскохозяйственная наука, 2017, № 1. pp. 58-61 (In Russian).

[2] Verbist K., Cornelis W.M., Schiettecatte W., Oltenfreiter G., Van Meirvenne M., Gabriels D. The influence of a compacted plough sole on saturation excess runoff. Engl. Soil Till. Res. 96, 2007, pp. 292-302.

[3] Ahmadi I.A power estimator for an integrated active-passive tillage machine using the laws of classical mechanics. Soil \& Tillage Research, 2017, No 171. - pp. 1-8.

[4] Fouda O.A. A Spiral Rotor Tiller for Tillage Heavy and Dry Clay Soil. J. Soil Sci. and Agric. Eng., Mansoura Univ., 2016,Vol. 7 (12), pp. 929-936.

[5] Borowski P., Klimkiewicz M., Powałka M. Selected problems of soil tillage systems and operations. Warsaw: WEMA. Warsaw University of Life Sciences, 2010. 133 p.

[6] Пути снижения энергоемкости чизельных почвообрабатывающих рабочих органов MOTROL (Ways to decrease energy consumption of chisel tillage working elements). Commission of Motorization and Energetics in Agriculture, 2009, vol. 11, pp. 179-189. (In Russian).

[7] Бабицкий Л.Ф., Москалевич V.U. Состояние и направления разработки чизельных вибрационных рыхлителей почвы (Current status and line of development of vibration soil looseners). Agricultural machinery, proceedings of the Crimean State Agrarian University: Механизация сельскохозяйственного производства: Сборник научных работ Крымского ГАУ. - Symferopol, 2002, pp. 10-14 (In Russian).

[8] Панов И.М., Ветохин В.И. Физические основы механики почв (Physical bases of soil mechanics). Киев: Феникс, 2008, 266 р. (In Russian)

[9] Булгариев Г.Г., Юнусов Р.Г. Обоснование и определение основных параметров спиральнопластинчатого рабочего органа (Substantiation and determination of the main parameters of the spiral-plate working element) Scientific journal of the Kazan State Agrarian University: Вестник Казанского государственного аграрного университета. Kazan: Kazan SAU, 2013, No 3(29), pp. 57-63. (In Russian)

[10]Бабицкий Л.Ф. Исследование и обоснование геометрических параметров рабочих органов культиваторов для противоэрозионной обработки почвы (Study and substantiation of the geometric parameters of the working elements of cultivators for erosion-preventive tillage). $\mathrm{PhD}$ disseratation work, Melitopol, 1979. (In Russian)

[11] Srivastava A., Carroll E., Roger P., Dennis R. Soil tillage. Engineering Principles of Agricultural Machines, 2nd ed., Michigan: American Society of Agricultural and Biological Engineers. 2006, pp.169-230.

[12]Булгариев Г. Г., Пикмуллин Г. В., Мухаметшин И. С. Ротационный рабочий орган для почвообрабатывающих орудий (Rotary working element of the tillage machines) «Scientific horizons - 2014»: Materials of the I International scientific and practical conference, 30.09.201407.10.2014. - Sheffield (UK): Science and Education Ltd, 2014, pp. 47-49 (In Russian).

[13] Мухаметшин И. С., Валиев А. Р., Макаров П. И. Патент РФ на изобретение 2522320, МПК7 A01B 13/08, 33/06, 49/02. Комбинированный плуг для гладкой вспашки (Patent of Russian Federation 2522320 Combined plough for flat ploughing) Claimed 12.02.2013; published 10.07.2014, Bulletin No 19, 10 p. (In Russian)

[14] Саакян С.С. Сельскохозяйственные машины (конструкция, теория и расчёт) (Agricultural machinery (design, theory and calculation) - Moscow: Изд-во с.-х. литературы, журналов и плакатов, 1962, 328 p. (In Russian)

[15]Гниломедов В.П. Обоснование новой формы стрельчатых лап культиватора для работы на повышенной скорости в условиях Юго-Востока (Substantiation of the new shape for sweep shares of cultivators for operation at increased speed in the conditions of South-East) Proceedings of the ВИСХОМ, issue No 20, Moscow, 1965. (In Russian) 